\title{
The Leeds regional quality control scheme for clinical biochemistry: A progress report
}

\author{
A. T. HOWARTH, R. L. NOBLE, R. B. PAYNE ${ }^{1}$, A. E. STEEL, AND P. R. TEASDALE \\ From Bradford Royal Infirmary, Huddersfield Royal Infirmary, Leeds (St James's) University Hospital, \\ Killingbeck Hospital, Leeds, and Hull Royal Infirmary.
}

SYNOPSIS The results from a regional quality control scheme for clinical biochemistry are analysed. Comparison with results from an earlier period shows that the quality of several of the 15 routine analyses has improved.

The methods by which the sera are produced and distributed, and the weekly results are analysed, are described. Each of the 25 laboratories receives an individual weekly computer printout within 24 hours of the deadline for the receipt of results. At the end of each six-month period a printout is produced ranking each laboratory for 'accuracy' and 'precision' for each test.

The Leeds regional quality control scheme has been operated without a break since 1967. Our early experience was reported at a national meeting of the Association of Clinical Biochemists (Toothill, 1969). This paper, by the members of the Executive Committee of the Leeds Region Committee for Clinical Biochemistry, deals with the last three years. It is hoped that the description of the modifications in the methods, some of the difficulties encountered, and the new studies which are being undertaken will be of value to those concerned with similar schemes.

\section{Samples and Analyses}

Originally the serum samples for analysis were despatched weekly from one laboratory to all participating laboratories. Sera are now prepared and distributed into tubes labelled with a week number. These are stored at $-20^{\circ} \mathrm{C}$ until they are distributed by hand to all participants at a meeting at the beginning of a six-month quality control period. Tubes labelled for each week of the subsequent six months are stored refrigerated in the participants' laboratories, and the correct numbered specimens removed each week for analysis. This eliminates both the administrative problems and the

${ }^{1}$ Reprint requests: Dr R. B. Payne, Department of Chemical Pathology, Leeds (St James's) University Hospital, Leeds LS9 7TF.

Received for publication 24 July 1973. cost of one laboratory having to package and mail a sample to each laboratory every week.

Liquid serum is used in our scheme to save the expense of freeze-drying and to eliminate the variation arising from errors in redissolving the dried material. Batches containing different concentrations of constituents are prepared from a horse serum which is variously diluted and to which known amounts of various substances are added. The analytical results for individual batches show that there is no significant deterioration of the specimens during the six-month period, and they compare well with the results of frequent repeated analyses over a longer period in the laboratory of the author preparing the samples.

Analysis of the specimen each week for sodium, potassium, chloride, urea, and glucose has been performed throughout the duration of the scheme. In addition, the following constituents have been estimated during the past three years: calcium, phosphate, total protein, albumin, creatinine, and uric acid. The degree of fluctuation of the weekly mean values and the standard error of the mean for these analyses confirm the earlier observations with electrolytes that the weekly mean of the 25 participating laboratories for each analysis is reasonably constant (Toothill, 1969). The values for one of the 10 batches analysed on three occasions during the last six-month period in 1972 are shown in table I. More recent studies on alkaline 
Table I Weekly mean (SEM) of analytical results from up to 25 laboratories on one of 10 different batches of serum analysed on three occasions during a 26-week period in 1972

phosphatase and protein-bound iodine are described later.

\section{Data Processing}

Originally results were returned to one laboratory and the means and standard deviations calculated with a desk calculator. However, computation of the results became an increasing problem, and the work involved led to delays in returning the results to participants. A computer became available to that laboratory and was used for a time, but changes in hardware necessitated programming changes and the time required in preparing the data caused this system to become impracticable. An approach to the Leeds Regional Hospital Board for the assistance of its Data Processing Section in producing and distributing the quality control results using their computer met with a favourable response. Participants now mail their results using a preprinted results form to arrive at the Regional Computer Centre before a deadline each week. The computer printouts are mailed back to the participating laboratories where they arrive only 24 hours after the receipt deadline. This rapid return of results enables participants to investigate errors or abnormalities almost immediately, and is one of the great assets of our local scheme.

The printout shows the number of laboratories participating in a particular test, the mean value, the standard deviation, and the coefficient of variation, together with 'corrected' values for these parameters after results outside 3 standard deviations have been omitted. Using these corrected values a histogram is printed showing the distribution of the results. The 2 standard deviation limits are marked on the abscissa along with the values for the limits of the line and the size of the steps along it. The participant's result is indicated by a distinctive sign (fig 1). The printout includes the participant's result, and both the number of standard deviations and the percentage by which it differs from the corrected mean value. The whole is repeated for each test substance. Each printout is thus unique to the participating laboratory. In addition to the individual printouts, a results summary of the values sent in by each laboratory, together with

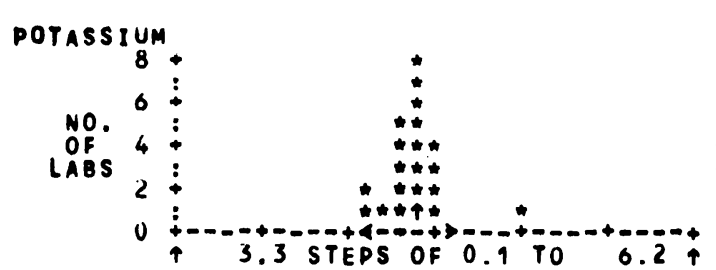

Fig 1 An example of the individual histogram received weekly by each laboratory for each analysis.

the mean, standard deviation, and coefficient of variation for each analysis is sent to the regional Quality Control Adviser.

We have recently, with the cooperation of the region's Data Processing Section, produced tablo $\vec{\theta}$ summarizing the six-monthly quality control resulte Laboratories were ranked for 'accuracy' for each. analysis on their average difference in percentages from the corrected weekly means over the whole of the six-month period. The standard deviation of the percentage differences from the weekly means for each analysis was also calculated. This is a measure of the variation about the average difference from the means and was used to rank laboratories for 'precision'.

We consider that the tables produced in this way give a reasonable indication of the overall? performance of each laboratory, including the effects of both analytical and reporting errors. The latter appeared to be not infrequent and were sometimes of a magnitude which might be of clinical importance. A second set of summary tables was produced after eliminating outliers of this nature by applying Chauvenet's criterion. ${ }^{1}$ These tables were thought to have excluded most reporting errors and $N$ thus gave a better measure of the true analytical performance of the laboratory concerned. An ${ }_{N}$ improved value in the second set of tables indi- $\mathscr{W}$ cated that divergent results in the original data, probably transcription errors, had been eliminated. Performance of individual laboratories varied $\mathbb{D}$

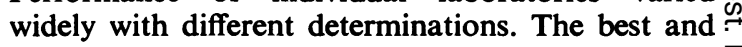
worst performance by individual laboratories for

${ }^{1}$ Documenta Geigy Scientific Tables, 5th edition (1956) p. 47. Geigy, Basle. 


\begin{tabular}{|c|c|c|c|c|c|}
\hline Protein & Albumin & Calcium & Phosphate & Uric Acid & Glucose \\
\hline $\begin{array}{l}6.21(0.06) \\
5.98(0.07) \\
6.18(0.07)\end{array}$ & $\begin{array}{l}2.56(0.10) \\
2.45(0.08) \\
2.51(0.06)\end{array}$ & $\begin{array}{l}10.65(0.14) \\
10.79(0.14) \\
10.62(0.11)\end{array}$ & $\begin{array}{l}5.21(0.11) \\
5.37(0.09) \\
5.38(0.09)\end{array}$ & $\begin{array}{l}4.99(0.14) \\
5.19(0.14) \\
5.15(0.17)\end{array}$ & $\begin{array}{l}119.7(2.62) \\
124.5(1.40) \\
121.8(1.87)\end{array}$ \\
\hline
\end{tabular}

Table I-continued

each test in the last six-month period in 1972 are shown in table II.

The analytical results from the most recent 20 weeks in 1972 have been compared with the results from the first 20-week period reported by Toothill (1969), using the criteria of Tonks (1963) which were adopted at that time. There has been an overall improvement in the proportion of laboratories reporting results within the specified limits of the weekly mean; but, perhaps more significantly, the performance of the worst laboratories in 1972 is considerably better than the performance of the worst laboratories in 1969 (table III). We hope that our regional scheme has contributed to these improvements. Nevertheless, there is clearly still considerable room for further improvement.

\section{Analytical Problems}

\section{UREA}

At one stage it became apparent that urea results from a few laboratories were significantly higher than those from the remaining laboratories. The laboratories obtaining high results proved to be those which used a method involving estimation of ammonia. Not all samples gave these anomalous results. Those which did were samples where the horse serum had been diluted to alter the electrolyte concentration and then albumin had been added to raise the protein concentration. Examination of all the solutions which had been added to the serum revealed that the albumin solution had a very high ammonium concentration, presumably residual

\begin{tabular}{|c|c|c|c|c|}
\hline \multirow[t]{2}{*}{ Analysis } & \multicolumn{2}{|c|}{ Average Difference from Weekly Mean (\%) } & \multicolumn{2}{|c|}{$\begin{array}{l}\text { Range of Differences }( \pm 2 S D) \text { about Own Mean } \\
\text { Difference (\%) }\end{array}$} \\
\hline & Best Performance & Worst Performance & Best Performance & Worst Performance \\
\hline $\begin{array}{l}\text { Sodium } \\
\text { Potassium } \\
\text { Chloride } \\
\text { Bicarbonate } \\
\text { Urea } \\
\text { Creatinine } \\
\text { Total protein } \\
\text { Albumin } \\
\text { Alkalin phosphatase } \\
\text { Calcium } \\
\text { Phosphate } \\
\text { Uric acid } \\
\text { Glucose }\end{array}$ & $\begin{array}{l}+0.03 \\
+0.07 \\
+0.04 \\
+0.03 \\
+0.05 \\
-0.84 \\
-0.26 \\
-0.14 \\
+0.44 \\
-0.26 \\
+0.67 \\
-0.34 \\
-0.82\end{array}$ & $\begin{array}{l}-1.8 \\
-\quad 3.6 \\
+4.3 \\
+8.8 \\
+6.8 \\
-30.7 \\
+5.8 \\
+40.2 \\
+49.9 \\
-6.6 \\
-8.9 \\
-18.5 \\
-21.5\end{array}$ & $\begin{array}{l} \pm 1 \cdot 1 \\
\pm 2 \cdot 7 \\
\pm 2 \cdot 2 \\
\pm 6 \cdot 8 \\
\pm 6 \cdot 0 \\
\pm 2 \cdot 4 \\
\pm 3 \cdot 3 \\
\pm 4 \cdot 7 \\
\pm 8 \cdot 9 \\
\pm 0 \cdot 3 \\
\pm 4 \cdot 7 \\
\pm 1 \cdot 1 \\
\pm 7 \cdot 8\end{array}$ & $\begin{array}{l} \pm 6 \cdot 1 \\
\pm 9 \cdot 7 \\
\pm 8 \cdot 2 \\
\pm 35 \cdot 8 \\
\pm 23 \cdot 9 \\
\pm 48.9 \\
\pm 13 \cdot 7 \\
\pm 31 \cdot 0 \\
\pm 48 \cdot 7 \\
\pm 30.7 \\
\pm 30 \cdot 3 \\
\pm 36.0 \\
\pm 33.7\end{array}$ \\
\hline
\end{tabular}

Table II Best and worst performances for individual laboratories over 26 weeks in 1972

\begin{tabular}{|c|c|c|c|c|c|c|c|}
\hline \multirow[t]{2}{*}{ Analysis } & \multirow[t]{2}{*}{ Limits } & \multicolumn{2}{|c|}{ Overall (\%) } & \multicolumn{2}{|c|}{ Best Performance ( $\%)$} & \multicolumn{2}{|c|}{ Worst Performance $(\%)$} \\
\hline & & 1969 & 1972 & 1969 & 1972 & 1969 & 1972 \\
\hline $\begin{array}{l}\text { Sodium } \\
\text { Potassium } \\
\text { Chloride } \\
\text { Urea } \\
\text { Glucose }\end{array}$ & $\begin{array}{l} \pm 3 \mathrm{mmol} / 1 \\
\pm 0.5 \mathrm{mmol} / 1 \\
\pm 3 \mathrm{mmol} / 1 \\
\pm 10 \% \\
\pm 10 \%\end{array}$ & $\begin{array}{l}71 \\
92 \\
79 \\
72 \\
69\end{array}$ & $\begin{array}{l}84 \\
96 \\
86 \\
90 \\
79\end{array}$ & $\begin{array}{l}100 \\
100 \\
100 \\
100 \\
100\end{array}$ & $\begin{array}{l}100 \\
100 \\
100 \\
100 \\
100\end{array}$ & $\begin{array}{l}45 \\
80 \\
35 \\
25 \\
33\end{array}$ & $\begin{array}{l}64 \\
91 \\
68 \\
82 \\
48\end{array}$ \\
\hline
\end{tabular}

Table III Percentage of analytical results falling within specified limits of the weekly mean values for all laboratories in the Leeds regional scheme over 20 weeks in 1969 and 20 weeks in 1972 
ammonium salt from a salting out procedure. The albumin was freed from ammonium ion by dialysis against water. Using the albumin solution purified in this way removed the source of error and the urea results from all laboratories became comparable.

\section{CALCIUM}

A few laboratories began to report abnormally low calcium values whilst others, including the laboratory where the specimens were prepared, obtained the expected values. Exchange of standards and the results from other quality control schemes suggested that the error was not due to faults in the method or apparatus of the laboratories concerned, nor could it be explained by the adsorption of calcium by plastic AutoAnalyzer sample cups reported by Hall and Whitehead (1970). A study of the problem was carried out by one of us. Sera stored at refrigerator temperature $\left(+4^{\circ}\right)$ or in a deep freeze $\left(-20^{\circ}\right)$ gave consistent results for many months; but sera stored in the freezing compartment of a domestictype refrigerator sometimes gave rise to low values. This was shown to be due to repeated thawing and freezing of the serum sample as the compartment temperature varied with opening and closing. At a temperature of approximately $-6^{\circ}$, when thawing began, microcrystals of calcium salt precipitated from the serum. These adhered very firmly to the walls of the plastic tubes used as containers and did not redissolve to any significant extent on thawing out at room temperature or after a brief period of warming at $37^{\circ}$. The serum removed from these tubes after storage under these conditions was thus depleted of calcium to a variable extent. A recommendation was therefore made to all participants to place the quality control sera on receipt into a deep freeze compartment of at least $-20^{\circ}$ and to leave it frozen solid until the day of analysis, when it is thawed out at $37^{\circ}$ and mixed well before sampling. With these precautions, consistent calcium results were obtained even on long storage. It is, of course, equally important that patients' samples are not stored in the freezing compartment of a domestic-type refrigerator.

\section{URIC ACID}

The range of normal and elevated values in the region's liquid quality control serum was obtained by adding uric acid dissolved in dilute sodium hydroxide to the horse serum. It was suspected that the uric acid results obtained by the majority of the participants in the scheme, who use colorimetric methods, might differ from the true uric acid values. A study was undertaken by one of us to compare the weekly mean for uric acid with the results obtained by replicate determinations in his laboratory on the

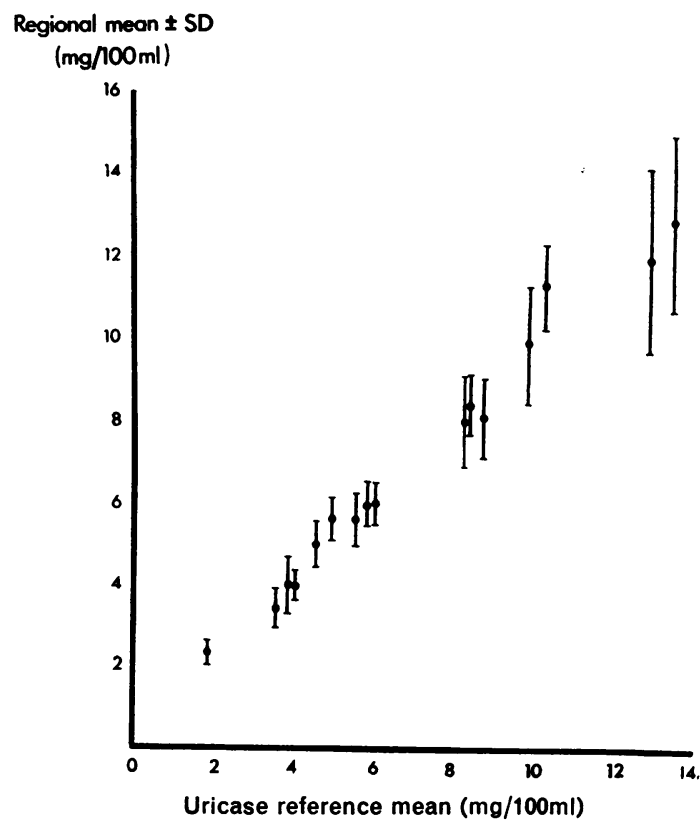

Fig 2 The relationship between the reference means for uric acid determined by a uricase method and the means $( \pm 1 S D)$ for the regional laboratories on 16 batches of serum analysed over 47 weeks.

same serum using a uricase method. The results for 15 batches over a period of 47 weeks are shown in figure 2. The scatter of results for individual batches is apparent. The mean values for the analysis of one batch on separate weeks differ, a typical example being $7 \cdot 77,8 \cdot 10$, and $8 \cdot 30 \mathrm{mg} / 100 \mathrm{ml}$. In spite of these variations the overall mean values do not differ markedly from the mean reference value obtained by a uricase-ultraviolet spectrophotometric method based on the technique of Praetorius and Poulsen (1953), with the exception of the two highest values. This was expected as most laboratories were using phosphotungstate methods, some of which depart from linearity above $9 \mathrm{mg} / 100$ $\mathrm{ml}$ (Steel, 1963).

\section{New Quality Control Studies}

PROTEIN-BOUND IODINE

A quality control scheme for protein-bound iodine (PBI) was initiated in 1971. In the Leeds region this estimation is carried out by only seven laboratories, most of which act as reference laboratories for other hospitals in the region. Five of the laboratories in the scheme use a fully automated technique (Technicon procedure N56), one a semi-automated 
technique with dry-ashing, and one an entirely manual method.

Each laboratory analysed each week an aqueous standard and a horse serum fortified with thyroglobulin, both prepared by one of us. The serum was sent out repeatedly on different weeks, interspersed with other sera of different PBI levels in an attempt to disguise the identity of the first specimen. Six of the seven laboratories analysed the serum before and after treatment with resin, as described in Technicon procedure N56. Aqueous standards were included both to provide a method whereby individual laboratories could judge their performance on a weekly basis, and also to assess accuracy.

The scheme was operated over two consecutive periods so that an assessment could be made of whether there had been any improvement in performance. Different horse sera, both fortified with thyroglobulin and stored at $-20^{\circ}$, were used. The regional mean values showed no significant change over several months when sera were stored under these conditions.

Because of the small number of participating laboratories, and the consequent uncertainty attached to the group weekly mean, the performance of individual laboratories could not be assessed by comparison of individual results with this parameter. The overall accuracy of individual laboratories was assessed by calculation of the mean percentage deviation from the known value of an aqueous standard analysed weekly. The iodine content of the standards varied between 4.0 and $6.0 \mu \mathrm{g} / 100 \mathrm{ml}$. An assessment of analytical precision was made by calculation of the standard deviation of the percentage deviation for these standards (table IV), and the precision was also assessed by calculating the standard deviation of the percentage deviation from the mean of the accumulated weekly results for the horse sera (table V). In calculating the mean values outliers were removed by applying Chau-

\begin{tabular}{|c|c|c|c|c|}
\hline \multirow[t]{2}{*}{ Laboratory } & \multicolumn{2}{|c|}{$\begin{array}{l}\text { Mean Percentage Diff- } \\
\text { erence from Actual } \\
\text { Value }\end{array}$} & \multicolumn{2}{|c|}{$\begin{array}{l}S D \text { of Percentage Diff } \\
\text { erence from Actual } \\
\text { Value }\end{array}$} \\
\hline & Period I & Period II & Period I & Period II \\
\hline $\begin{array}{l}1 \\
2 \\
3 \\
4 \\
5 \\
1 \mathrm{M} \\
2 \mathrm{M}\end{array}$ & $\begin{array}{r}+1.56 \\
-0.46 \\
+2.25 \\
+4.05 \\
+14.50 \\
+0.02 \\
+0.74\end{array}$ & $\begin{array}{l}+1.56 \\
+0.33 \\
-11.63 \\
-1.20 \\
+1.44 \\
-3.32 \\
+1.47\end{array}$ & $\begin{array}{r}5 \cdot 8 \\
38 \cdot 8 \\
18 \cdot 4 \\
7 \cdot 1 \\
12 \cdot 6 \\
5 \cdot 1 \\
10 \cdot 2\end{array}$ & $\begin{array}{c}5 \cdot 7 \\
8 \cdot 3^{2} \\
9 \cdot 1^{1} \\
5 \cdot 0 \\
12 \cdot 6 \\
2 \cdot 4^{1} \\
12 \cdot 3\end{array}$ \\
\hline
\end{tabular}

Table IV Mean and SD percentage differences of $P B I$ values from the actual iodine content of aqueous standards over two four-month periods

Comparison of SD (F-test): ${ }^{1} P<0.011^{2} P<0.001$

\begin{tabular}{|c|c|c|c|c|}
\hline \multirow[t]{2}{*}{ Laboratory } & \multicolumn{2}{|c|}{$\begin{array}{l}\text { Mean Percentaxe Difference } \\
\text { from Overall Mean }\end{array}$} & \multicolumn{2}{|c|}{$\begin{array}{l}S D \text { of Percentage Diff- } \\
\text { erence from Overall } \\
\text { Mean }\end{array}$} \\
\hline & $\begin{array}{l}\text { Period I } \\
\text { (overall mean } \\
8.15 \mathrm{\mu g} / 100 \mathrm{ml})\end{array}$ & $\begin{array}{l}\text { Period II } \\
(\text { overall mean } \\
6.55 \mathrm{\mu g} / 100 \mathrm{ml})\end{array}$ & Period I & Period II \\
\hline $\begin{array}{l}1 \\
2 \\
3 \\
4 \\
5 \\
2 \mathrm{M}\end{array}$ & $\begin{array}{r}-2.2 \\
+1.8 \\
-11.8 \\
-3.8 \\
+15.3 \\
+0.6\end{array}$ & $\begin{array}{r}+4.4 \\
+0.3 \\
-14.3 \\
-\quad 1.8 \\
+\quad 8.9 \\
+\quad 2.7\end{array}$ & $\begin{array}{r}4 \cdot 7 \\
9 \cdot 3 \\
10 \cdot 0 \\
5 \cdot 4 \\
9 \cdot 7 \\
4 \cdot 1\end{array}$ & $\begin{array}{r}5.0 \\
9.0 \\
14.3 \\
6.8 \\
11.4 \\
7.0\end{array}$ \\
\hline
\end{tabular}

Table V Mean and $S D$ percentage differences of $P B I$ values without resin treatment from overall mean values for two horse sera during 13- and 18-week periods

venet's criterion. The results for one manual laboratory, which although consistent were significantly low, have been omitted from the calculations in table $\mathrm{V}$.

The average percentage deviation from the true iodine content of aqueous standards shows that standardization was a problem with laboratory no. 5 in period I and laboratory no. 3 in period II (table IV). Three of the laboratories showed encouraging signs of improvement in the precision of analyses of the aqueous standard in the second period (table IV), but this was not reflected in the results for the analyses of the horse sera (table $\mathrm{V}$ ).

Resin treatment was found to have affected the analytical precision of two laboratories significantly (F-test: $P<0.05$ ). This observation led to the discovery of faulty batches of Technicon resin, and to the conclusion that new batches should be checked before use.

\section{ALKALINE PHOSPHATASE}

A regional scheme for alkaline phosphatase has been in operation for about three years, and a detailed report of the method and material used and of the preliminary results has been published (Teasdale, 1973).

Heat-inactivated horse sera fortified with human liver alkaline phosphatase are distributed with the other quality control sera and stored frozen for up to six months. Each week a numbered specimen is analysed both by the participating laboratories using their routine methods and also, in duplicate, by five reference laboratories which have a common stock phenol standard, using the manual method of Kind and King (1954) recommended as an acceptable reference method by Moss, Baron, Walker, and Wilkinson (1971). An example of the agreement now achieved between the mean regional results and the mean reference values is shown in figure 3 .

A small but steady deterioration in the activity of the frozen sera has been found throughout the 
Table VI Rate of fall of alkaline phosphatase activity determined by reference laboratories in sera stored frozen for up to six months

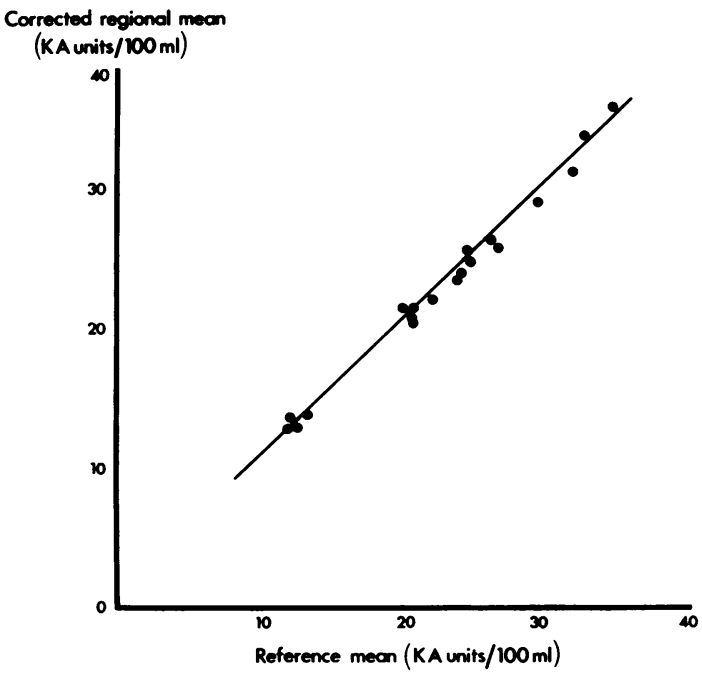

Fig 3 The relationship between the reference means for alkaline phosphatase determined by the method of Kind and King (1954) and the means for the regional laboratories after elimination of outlying values over 26 weeks.

six-month period, and the rate of fall is greater the higher the initial activity of the serum, averaging $1 \%$ a week (table VI). This fall does not detract from the usefulness of the prepared sera for quality control, since the routine results are compared with the reference value determined on the same day. However, it has modified our ideas on a regional 'calibrated' serum standardized by replicate analyses by the reference laboratories, which was introduced with the object of improving accuracy at the request of the paticipating laboratories as a result of the first report (Teasdale, 1973). The serum is now known to have a much shorter life than we had hoped.

The participating laboratories all report in $\mathrm{KA}$ units $/ 100 \mathrm{ml}$, and their $95 \%$ normal ranges for healthy adults are all close to 3 to $13 \mathrm{KA}$ units/100 $\mathrm{ml}$. We think it is particularly important that laboratories should be able to distinguish consistently between a serum at the upper end of the normal

\begin{tabular}{lll}
\hline & $\begin{array}{l}\text { Six Months Ending } \\
\text { November 1971 }\end{array}$ & $\begin{array}{l}\text { Six Months Ending } \\
\text { November 1972 }\end{array}$ \\
\hline Total results & $86(100 \%)$ & $110(100 \%)$ \\
Equivocal values & $28(33 \%)$ & $24(22 \%)$ \\
Raised values & $17(20 \%)$ & $10(9 \%)$ \\
\hline
\end{tabular}

Table VII Improvement in the proportion of equivocal and raised alkaline phosphatase values reported on $a$ normal serum during two six-month periods

range and one slightly but significantly outside it. A normal serum with a reference value of $12 \mathrm{KA}$ units $/ 100 \mathrm{ml}$ was analysed during two periods of six months separated by an interval of one year. Results reported between 13 and 15.5 KA units/100 $\mathrm{ml}$ were considered to be 'equivocal' and resulto over $15.5 \mathrm{KA}$ units $/ 100 \mathrm{ml}$ 'raised'. The numbers oథ results falling into the normal, equivocal, anfs. raised categories during the two periods are show in table VII. We consider that the fall in the proportion of both equivocal and raised values reported on this normal serum is encouraging.

We are indebted to Mr R. D. Steele, Data Processing Manager, Leeds Regional Hospital Board, and his colleagues at the Regional Computer Centre for undertaking the data handling, and for cheerfully accepting the modifications we have introduced to the original programme.

\section{References}

Hall, R. A., and Whitehead, T. P. (1970). Adsorption of serum calcium by plastic sample cups. J. clin. Path., 23, 323-326.

Kind, P. R. N., and King, E. J. (1954). Estimation of plasma phosphatase by determination of hydrolysed phenol with aminoantipyrine. J. clin. Path., 7, 322-326.

Moss, D. W., Baron, D. N., Walker, P. G., and Wilkinson, J. H. (1971). Standardisation of clinical enzyme assays. J. clin. Path., 24, 740-743.

Praetorius, E., and Poulsen, H. (1953). Enzymatic determination of uric acid, detailed directions. Scand. J. clin. Lab. Invest., 5, 273-280.

Steel, A. E. (1963). A comparison of eleven methods for the determination of serum uric acid. Proc. Ass. clin. Biochem., 2, 211-212.

Teasdale, P. R. (1973). A report on the regional Quality Control of serum alkaline phosphatase. Ann. clin. Biochem., 10, 57-60.

Tonks, D. B. (1963). A study of accuracy and precision of clinical chemistry determinations in 170 Canadian laboratories. Clin. Chem., 9, 217-233.

Toothill, C. (1969). A regional quality control scheme. Ann. clin. Biochem.. 6, 138-142. 